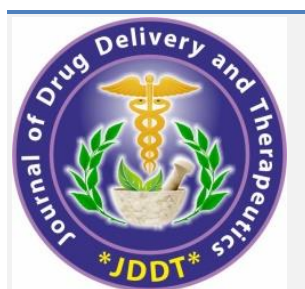

Open Access Full Text Article

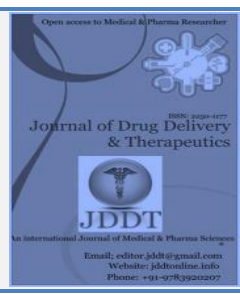

Review Article

\title{
A Review on Central Pontine Myelinolysis and Correction of Hyponatremia in Hospitalized Patients
}

\author{
*Anju Joy (D), Bincy T. Abraham, K. Krishnakumar \\ Department of Pharmacy Practice, St. James college of Pharmaceutical Sciences, St. James' Hospital Trust Pharmaceutical Research Centre (DSIR \\ Recognized), Chalakudy-680307, Kerala, India
}

\section{Article Info:}

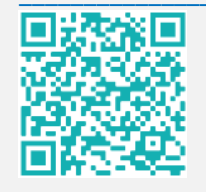

Article History:

Received 14 May 2021

Review Completed 23 June 2021

Accepted 30 June 2021

Available online 15 July 2021

Cite this article as:

Joy A, Abraham BT, Krishnakumar K,_A Review on Central Pontine Myelinolysis and Correction of

Hyponatremia in Hospitalized Patients, Journal of Drug Delivery and Therapeutics. 2021; 11(4):138-140 DOI: http://dx.doi.org/10.22270/jddt.v11i4.4876

\author{
Abstract
}

Pontine myelinolysis (PM) can be a nerve disorder represented by pons demyelination. it is characterized by damage to regions of the brain, most commonly tracts pontine substantia alba, after rapid correction of metabolic disorders such as hyponatremia. PM (Pontine Myelinolysis) is categorized into Central pontine myelinolysis (CPM) and extra pontine myelinolysis (EPM). The various studies revealed that quick correction of hyponatremia plays a vital role in the pathogenesis of ODS. Prevention of ODS must be conducted by gradually increasing sodium concentration of 4-6 mmol/Lin in any 24-h period. PubMed and Medline literature search was done using CPM and hyponatremia as keywords. The principal aim of this review is to encapsulate, the recent evidence from literature about the association between rapid correction of hyponatremia and central pontine myelinolysis.

Keywords: Demyelination syndrome, EPM, CPM, Serum tonicity, Hyponatremia, Demyelination

*Address for Correspondence:

Anju Joy, Department of Pharmacy Practice, St. James college of Pharmaceutical Sciences, St. James' Hospital Trust Pharmaceutical Research Centre (DSIR Recognized), Chalakudy-680307, Kerala, India. ORCID ID: https://orcid.org/0000-0002-1349-1449

\section{INTRODUCTION}

Central pontine myelinolysis could also be a neurological disorder that the majority of frequently occurs after too rapid medical correction of sodium deficiency (hyponatremia). It was first described in 1959 by Adams and his colleagues during a report of 4 patients with pseudobulbar palsy and quadriplegia. The starting cases were seen in patients with alcohol use disorder and malnutrition; nevertheless, by the 1970s, successive cases showed a link with rapid sodium correction. ${ }^{1}$

The rapid rise in serum sodium (osmolarity), results in water moving out of the cell leading to their dryness and destruction of myelin. Pons is the main part of the brain which is exposed by myelinolysis. Myelinolysis may affect the other areas of the brain, which is called extra pontine myelinolysis. ${ }^{2}$

Clinical features of CPM usually begin to appear several days after the rapid correction of low sodium. Symptoms may vary and can range from encephalopathy to coma and death.

\section{EPIDEMIOLOGY}

The incidence of CPM is not well known due to underdiagnosis. A 2015 retrospective study shows that the prevalence of ODS is $2.5 \%$ between ICU admissions.
- About $25 \%$ of patients with severe hyponatremia have neurological complications after rapid sodium correction.

- Patients having chronic hyponatremia showed higher rates of neurological complications.

\section{SIGNS AND SYPMTOMS}

- Damage to corticobulbar tracts (pseudobulbar palsy); includes facial weakness, dysphagia, diplopia and dysarthria

- Damage to corticospinal tracts: spastic quadriparesis

- Further symptoms are impaired thinking, paralysis within the arms and legs, stiffness, impaired sensation, and difficulty with coordination.

- The condition can eventually lead to "locked in syndrome" (which is characterized by complete paralysis of all voluntary muscles with preservation of vertical eye movement and blinking. ${ }^{3}$

- The patient cannot communicate verbally even though he is conscious and cognitively impaired. This is similar to if someone wakes up in sleep paralysis. 


\section{COMMON CLINICAL SYMPTOMS BY SITE OF MANIFESTATION AND SYNDROME CLASSIFICATION}

\begin{tabular}{|l|l|l|}
\hline CPM & \multicolumn{2}{|c|}{ EPM } \\
\hline Pontine symptoms & Movement disorders & Neurobehavioral problems \\
\hline Coma & Bradykinesia,rigidty & Encephalopathy \\
\hline Locked- in syndrome & Tremor & Epileptic seizures \\
\hline Paresis & Dystonia & Mutism \\
\hline Dysarthria & Chorea,choreoathetosis & Catatonia \\
\hline Dysphagia & Myoclonus & Apathy, lethargy \\
\hline Pupillary and Ocular motility disorders & Gait disorder & Depression \\
\hline Loss of reflexes & Ataxia & Emotional instability,dementia \\
\hline
\end{tabular}

\section{ETIOLOGY}

- The most common cause is overly-rapid correction of low blood sodium levels.

- It is also in patients suffering from chronic alcohol withdrawal symptoms, the event may also not be related at all to hyponatremia

- It could affect patients who take some prescription medicines that are permeable to $\mathrm{BBB}$ and cause abnormal thirst response - in this state the CPM is caused by leading to low blood sodium levels.

- In patients with, inadequate thirst response leads to extreme water intake, strictly diluting serum sodium. ${ }^{4}$

- It may also occur in patients susceptible to hyponatremia affected by

- Chronic liver disease

- Liver transplantations

- Hypokalemia

- Severe burns

- Malnutrition

- Alcoholism

- Severe electrolyte disorder

- Patient with serum sodium less than $105 \mathrm{~m} \mathrm{Eq/L}$

\section{PATHOPHYSIOLOGY}

- The Normal sodium level in our body is $135-145 \mathrm{~m} \mathrm{Eq} / \mathrm{L}$. If it is below that of $135 \mathrm{~m} \mathrm{Eq} / \mathrm{L}$, that condition is called Hyponatremia. When there is a decrease in serum tonicity, ECF will move to the intracellular space of greater tonicity through the osmosis.

- It is the attempt to normalize the gradient, thus causing cerebral edema.

- The brain is able to adjust to a decline in serum tone through different methods. The first way is the movement of water from intracellular space into the CSF. glycine, etc.) with water, which will decrease cell swelling.

- Consequently, patients have already developed compensatory mechanisms including the loss of solutes, which puts them at an increased risk of progressing CPM. 5

- With the quick correction of hyponatremia, the brain cannot recover the lost osmolytes, leading to dehydration of the brain tissue and demyelination of the white matter. So, the sodium correction rate should not above 8-12 m Eq / L / day otherwise complications will occur.

- When hyponatremia is corrected too rapidly by giving hypertonic saline, there is not enough time for brain cells to adjust to a new environment as they cannot produce enough osmolytes in a short time. This results in cells losing fluid and breakdown of myelin follows 6

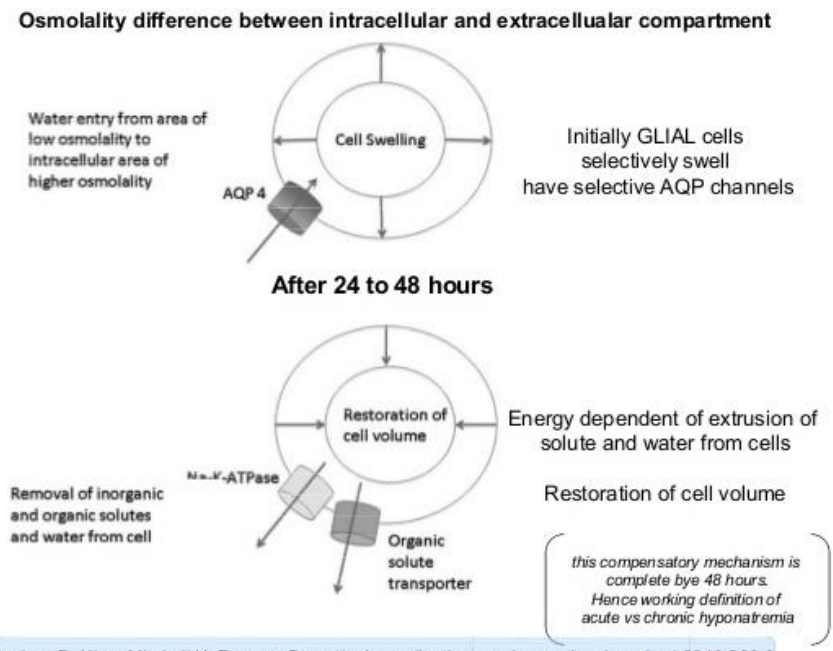

Joshua D. King, Mitchell H. Rosner. Osmotic demyelination syndrome. Am J med sci 2010:339:6

Figure 1: Restoration of cellular space in the settings of hyponatremia 7

- The second way is called regulatory decrease in volume, in that intracellular solutes and water will be eliminated through ion channels to decrease brain inflammation and balance the brain volume. In chronic hyponatremia, there is a release of organic osmolytes (glutamate, 


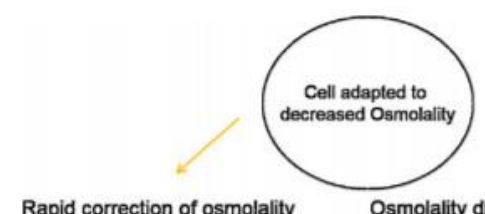

Rapid correction of osmolality

Osmolality difference between two compartments (Hypertonic ECF),

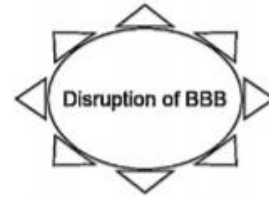

-Exposure of glial cells to cytokines, complements

-Axonal shear injury

Figure 2: Demyelination and apoptosis of cells with quick correction of hyponatremia 8

\section{DIAGNOSIS}

The suspicion is established by the demonstration by magnetic resonance of the demyelination sites, typically positioned in the pons, cerebellum, lateral geniculate body, thalamus and external and terminal capsules. Brain stem damage can be detected by electrophysiological diagnoses as supporting evidence.

\section{TREATMENT}

The primary treatment of CPM is to adjust sodium.it should not be more than 8 to $12 \mathrm{~m} \mathrm{Eq} \mathrm{/} \mathrm{L} \mathrm{for} 24$ hours. if the patients had acute hyponatremia, the rate of adjusting the sodium should not more than 6 to $8 \mathrm{~m} \mathrm{Eq} / \mathrm{L}$ for 24 hours. 9

In case of chronic or severe hyponatremia (serum sodium less than $120 \mathrm{~m} \mathrm{Eq} \mathrm{/} \mathrm{L)} \mathrm{with} \mathrm{neurological} \mathrm{symptoms,} \mathrm{a}$ $3 \%$ hypertonic saline solution should be given.

If the patient had no other neurological symptoms, the main aim of the treatment is slow sodium correction rate with iv fluids not more than 8 to $12 \mathrm{~m} \mathrm{Eq} \mathrm{/} \mathrm{L} \mathrm{for} 24$ hours. Patient serum sodium should be monitored for every 46hours during the time of iv therapy.

\section{COMPLICATIONS}

Complications of CPM include venous thromboembolism, ventilator dependence, muscle wasting, infections such as urinary tract infections, aspiration pneumonia and pressure sores.

\section{SUPPORT THERAPY}

It includes respiratory support, physical therapy and intensive rehabilitation, and antiparkinsonian medications.

\section{PATIENT EDUCATION}

Patients must be well educated about the disease condition, therapy options and the clinical outcome of the disease. 10

They have to participate in follow-up at regular intervals after hospital discharge to better assess their clinical clarification.

\section{IMPROVE THE RESULTS OF THE HEALTHCARE TEAM}

- The primary goal of the therapy is prevention of the disease. CPM is mainly associated with rapid correction of hyponatremia. ${ }^{11,12}$

- It is a reversible disease so it should be recognized as soon as possible and clinical interventions are initiated quickly.

- The physicians and other healthcare teams have to take this as a challenging situation.

- The prevention of the disease is carried out by controlling the serum sodium of the patients. Serum sodium of patients having CPM should be monitored every 4-6 hours.

- The current treatment is to maintain the sodium correction rate between 8 and $12 \mathrm{mEq} / \mathrm{L}$ for $24 \mathrm{hrs}$.

\section{CONCLUSION}

- Rapid adjustment of hyponatremia acts as a fundamental role in the development of ODS. In particular, CPM almost always relies on other underlying situations, such as chronic alcoholism and liver cirrhosis, correction of chronic hyponatremia, as well as burns and liver transplants.

- Prevention of ODS carried out by gradually increasing the sodium concentration from 4-6 mmol / Lin over a 24hour period.

\section{REFERENCES}

1. Norenberg MD, Leslie KO, Robertson AS, Association between rise in serum sodium and central pontine myelinolysis, Annals of Neurology Official Journal of the American Neurological Association and the Child Neurology Society, 1982; 11(2):128-35. https://doi.org/10.1002/ana.410110204

2. Laureno R, Central pontine myelinolysis following rapid correction of hyponatremia, Annals of Neurology, Official Journal of the American Neurological Association and the Child Neurology Society, 1983; 13(3):232-42. https://doi.org/10.1002/ana.410130303

3. Menger $\mathrm{H}$, Jorg J, Outcome of central pontine and extrapontine myelinolysis ( $\mathrm{n}=44$ ), Journal of neurology, 1999; 246(8):700-5 https://doi.org/10.1007/s004150050435

4. Singh T D, Fugate J E, Rabinstein AA, Central pontine and extrapontine myelinolysis a systematic review, European Journal of Neurology, 2014; 21(12):1443-50. DOI: https://doi.org/10.1111/ene.12571

5. Graff-Radford J, Fugate JE, Kaufmann TJ, Mandrekar JN, Rabinstein AA, Clinical and radiologic correlations of central pontine myelinolysis syndrome, In Mayo Clinic Proceedings 2011; 86(11):1063-1067 DOI: https://doi.org/10.4065/mcp.2011.0239

6. Alleman AM, Osmotic demyelination syndrome: central pontine myelinolysis and extrapontine myelinolysis. In Seminars in Ultrasound, CT and MRI 2014; 35(2):153-159 DOI: https://doi.org/10.1053/j.sult.2013.09.009

7. King JD, Rosner MH, Osmotic demyelination syndrome, Am J Med Sci, 2010 Jun; 339(6):5617. https://doi.org/10.1097/MAJ.0b013e3181d3cd78 .

8. Renjen PN, Chaudhari D, Namala V, Central pontine and extrapontine myelinolysis, Apollo Medicine, 2016; 13(4):220-223. https://doi.org/10.1016/j.apme.2016.11.001

9. Sterns RH, Silver S, Kleinschmidt De Masters BK, Rojiani AM, Current perspectives in the management of hyponatremia prevention of CPM, Expert review of neurotherapeutics, 2007; 7(12):1791-7. https://doi.org/10.1586/14737175.7.12.1791

10. Sterns RH, Hix JK, Silver S. Treating profound hyponatremia a strategy for controlled correction, American journal of kidney diseases, 2010; 56(4):774-9. https://doi.org/10.1053/j.ajkd.2010.04.020

11. Sterns RH, Hix JK, Overcorrection of hyponatremia is a medical emergency, Kidney international, 2009; 76(6):587-9. DOI: https://doi.org/10.1038/ki.2009.251

12. Kengne FG, Soupart A, Pochet R, Brion JP, Decaux G, Re-induction of hyponatremia after rapid overcorrection of hyponatremia reduces mortality in rats, Kidney international, 2009; 76(6):614-21. DOI: https://doi.org/10.1038/ki.2009.254 